\title{
INTERPRETATION AND IMPLICATION IN THE SUPREME COURT
}

WELLS was struggling to sell some flats. He mentioned this to a neighbour, who put Wells in touch with Devani. Wells and Devani spoke over the telephone. The trial judge found that Devani told Wells that he was an estate agent, and his usual commission was $2 \%+$ VAT. Wells agreed to this, but the parties did not expressly agree upon what was to trigger the commission.

Devani subsequently introduced a purchaser to Wells who bought the flats. Was there a binding contract between Wells and Devani? The trial judge found that there was, but the majority of the Court of Appeal, surprisingly, overturned that decision ([2016] EWCA Civ 1106, [2017] Q.B. 959, noted [2018] C.L.J. 22). The Supreme Court has sensibly allowed the appeal: Wells v Devani [2019] UKSC 4.

The majority of the Court of Appeal thought the contract was incomplete because an essential term, namely the event which was to trigger the commission, still had to be agreed. That view was strongly rejected by the Supreme Court and orthodoxy restored. It is often the case that crucial terms, such as the price, are not expressly agreed, and the court can imply a term that a reasonable price be paid (see e.g. Sale of Goods Act 1979, s.8). As Steyn L.J. observed in G. Percy Trentham Ltd. v Archital Luxfer Ltd. [1993] 1 Lloyd's Rep. 25, at 27:

The fact that the transaction was performed on both sides will often make it unrealistic to argue that there was no intention to enter into legal relations. It will often make it difficult to submit that the contract is void for vagueness or uncertainty. Specifically, the fact that the transaction is executed makes it easier to imply a term resolving any uncertainty, or, alternatively, it may make it possible to treat a matter not finalised in negotiations as inessential.

In Wells v Devani, Lord Kitchin (with whom Lords Wilson, Sumption, Carnwath and Briggs agreed) similarly emphasised (at [18]) that "the courts are reluctant to find an agreement is too vague or uncertain to be enforced where it is found that the parties had the intention of being contractually bound and have acted on their agreement". Courts may, perhaps, not be so willing to dismiss concerns of vagueness or uncertainty where an agreement is wholly executory (cf. May and Butcher $v$ R. [1934] 2 K.B. 17), but that was not the case in Wells 
$v$ Devani. The Supreme Court rightly held that the contract was sufficiently certain and complete, and that the commission had to be paid upon completion of the transaction.

The most interesting aspect of the Supreme Court's decision lies in the route taken to reach that result. Unlike the trial judge and Steyn L.J. in Percy Trentham (quoted above), Lord Kitchin preferred to base his reasoning upon interpretation rather than implication of terms. Yet Lord Kitchin recognised that there was no express term regarding the precise event which would entitle Devani to his commission. Given the lack of an express term, what was being interpreted? Lord Kitchin thought that the parties agreed that the commission was payable on finding a "purchaser", and that a string of cases regarding estate agents showed that "purchaser" should reasonably be understood as requiring completion of the sale. But often a party may be considered to be the "purchaser" upon exchange of contracts, and the trial judge did not find that the term "purchaser" was agreed (transcript, para. 2.2). In the Court of Appeal, Lewison L.J. - recognised by Lord Briggs in the Supreme Court (at [58]) to have "a pre-eminent standing in relation to the interpretation of contracts" adopted a more orthodox approach in observing that ([2016] EWCA Civ 1106, [2017] Q.B. 959 at [39]):

If one is to interpret a contract, the first question (where the contract is oral) must be: what words were spoken? The judge made a clear finding of fact that nothing was said about the trigger event. Thus in my judgment this route entails the interpretation of words that, on the judge's findings, were never spoken.

It is perhaps significant that Wells $v$ Devani concerned an oral contract. (Indeed, by not providing Wells with his written terms of business before undertaking any work, Devani failed to comply with his obligations under the Estate Agents Act 1979 and the judge held that the amount recoverable by Devani should be reduced by one third. Both the Court of Appeal and Supreme Court refused to overturn the judge on this point, although space precludes further consideration of the issue.) Most commercial contracts, however, are in writing; Chitty on Contracts (33rd edn, 2018, para. 13-041) accurately states that interpretation "denotes the process $\ldots$ by which a court arrives at the meaning to be given to the language used by the parties in the express terms of a written agreement". The focus of interpretation should be upon the express terms of the contract. Interpreting silence is inherently ambiguous and prone to error.

The same result in Wells $v$ Devani could have been reached through implication. Indeed, Lord Kitchin recognised that if the contract, on its proper 
interpretation, did not provide for a trigger event then a term that the commission be paid upon completion "must be implied to make the contract work and to give it practical and commercial coherence" (at [29]). Whereas the majority of the Court of Appeal had thought that a term could not be implied to complete the contract, the Supreme Court adopted a much more pragmatic approach. Whether a contract is sufficiently certain or complete should be assessed once all the express and implied terms have been ascertained. Lord Kitchin even said that "it is possible to imply something that is so obvious that it goes without saying into anything, including something the law regards as no more than an offer" (at [33]). This is sensible, and any suggestions to the contrary that might be found in cases such as Scancarriers A/S v Aotearoa International Ltd. [1985] 2 Lloyd's Rep. 419 (PC) and Little v Courage Ltd. (1995) 70 P. \& C.R. 469 should no longer be followed.

The decision of the Supreme Court raises once again the relationship between interpretation and implication. A broad approach to interpretation risks swallowing up much of implication. This was a potential consequence of Attorney-General of Belize v Belize Telecom Ltd [2009] UKPC 10, [2009] 1 W.L.R. 1988, but the Supreme Court in Marks and Spencer plc v BNP Paribas Securities Services Trust Co (Jersey) Ltd. [2016] UKSC 72, [2016] A.C. 742 helpfully insisted that interpretation and implication should be kept distinct. Lord Neuberger said (at [27]):

When one is implying a term or a phrase, one is not construing words, as the words to be implied are ex hypothesi not there to be construed; and to speak of construing the contract as a whole, including the implied terms, is not helpful, not least because it begs the question as to what construction actually means in this context.

By contrast, in Wells $v$ Devani their Lordships were effectively construing the contract as a whole. But the distinction between interpretation and implication should not be blurred. Whereas all express terms have to be interpreted, no term should be implied unless necessary to do so. And terms which are implied into a contract still need to be interpreted.

Unfortunately, the guidance provided by the Supreme Court on matters of interpretation continues to vacillate. Lord Sumption has observed, extrajudicially, that decisions such as Arnold v Britton [2015] UKSC 36, [2015] AC 1619 have signalled a shift in emphasis towards the natural meaning of contractual language, and away from relying upon the importance of background factors (compare the approach adopted by Lord Hoffmann in cases such as Investors Compensation Scheme Ltd. $v$ West Bromwich Building Society 
[1998] 1 W.L.R. 896 and Chartbrook Ltd. v Persimmon Homes Ltd. [2009] UKHL 38; [2009] 1 A.C. 1101). Yet Lord Sumption also recognised that although "the Supreme Court has begun to withdraw from the more advanced positions seized during the Hoffmann offensive" it has done so in "muffled tones" ("A Question of Taste: The Supreme Court and the Interpretation of Contracts" (2017) https://www.supremecourt.uk/docs/speech-170508.pdf). Perhaps the retreat should have been sounded more loudly. In Wells v Devani, Lord Briggs said (at [59]) that "the context in which the words are used, and the conduct of the parties at the time when the contract is made, tells you as much, or even more, about the essential terms of the bargain than do the words themselves". The context of these remarks is, in turn, important: Wells $v$ Devani did not concern a written contract, let alone a detailed agreement drafted by lawyers which is typical in commercial litigation. Nevertheless, Lord Briggs' remarks chime much better with Lord Hoffmann's approach than with Lord Neuberger's more recent leading decisions in cases such as Arnold v Britton and Marks and Spencer v BNP Paribas which have (it is suggested sensibly) stressed the primacy of the language chosen by the parties. Such tension in the authorities is regrettable, and it is to be hoped that it does not relaunch an apparently endless stream of appeals on points of interpretation to our apex court.

PAUL S. DAVIES

Address for correspondence: Faculty of Laws, University College London, Bentham House, 4-8 Endsleigh Gardens, London, WC1H OEG. Email: paul.s.davies@ucl.ac.uk 